\title{
Study on the Linkage between RMB and One Belt And One Road National Currency Exchange Rate and Its Influencing Factors
}

\author{
Cong Wang ${ }^{1, a}$ \\ ${ }^{1}$ Shandong university of Finance and Economics, Shandong Jinan, China \\ a18254149158@163.com
}

\begin{abstract}
This paper mainly studies the linkage between RMB and "One Belt And One Road" on behalf of the national currency exchange rate and the factors that influence the linkage, and tests the linkage through the var-dcc-garch model. The results show that the fluctuation of RMB exchange rate has an obvious mean spillover effect on the selected "One Belt And One Road" countries, and there is a linkage between them.
\end{abstract}

Keywords: VAR-DCC-GARCH, mean overflow, correlation

\section{INTRODUCTION}

Comrade Jinping Xi jinping put forward the "One Belt And One Road" cooperation initiative, which aims to promote the coordinated development and common progress of China and countries along the belt and road on the basis of strengthening the cooperation between currencies. According to statistics, the scale of cross-border trade settlement in RMB between China and countries along the "One Belt And One Road" has increased significantly, which has improved the international recognition of RMB to some extent.

From July 2005 to June 2010, the exchange rate reform made the RMB exchange rate start to float in both directions and get closer to the real market exchange rate. In addition, with the "One Belt And One Road" cooperation initiative in 2013 and the "8.11" exchange rate reform in 2015, more countries along the "One Belt And One Road" have their exchange rates floating with the RMB than before. However, can these measures further enhance the international influence of the RMB and thus enhance the linkage with the exchange rates of countries along the "One Belt And One Road"?

In this context, what linkage characteristics do the RMB and currencies of countries along the "One Belt And One Road" show? Therefore, this paper expands the scope of research and empirically analyzes the linkage between RMB and currency exchange rates of countries along the "One Belt And One Road". Finally, according to the empirical results to provide corresponding policy recommendations.

\section{DATA SELECTION AND MODEL SETTING}

\subsection{Data Description and Selection}

This paper selects the daily exchange rate trading data of China and 14 "One Belt And One Road" countries released by the international monetary fund (IMF) on July 21, 2005 and solstice on March 29, 2019. In order to investigate the impact of the RMB exchange rate system reform and the global financial crisis, this paper divided the selected data into stages. Stage 2:2008.7.20-2010.6.19; The third stage: 2010.6.20-2015.8.11; The fourth stage of "8.11" exchange rate reform -2019.3.29. In this paper, logarithmic processing is performed on the exchange rate data, and 62388 sample values are obtained by taking the first-order difference.

\subsection{Model Description}

The research focus of this paper is the linkage between currency exchange rates and the factors that influence the linkage. Therefore, garch-bekk model was not adopted, but the basic dcc-garch model was selected for research.

\section{THE EMPIRICAL ANALYSIS OF EXCHANGE RATE LINKAGE}

\subsection{Test of Optimal Lag Order of VAR}

In this paper, SC criterion is used to determine the optimal lag period of VAR model. 
Table 1 The optimal lag order information of VAR model

\begin{tabular}{|c|c|c|c|c|c|}
\hline & Order number & & Order number & & \\
\hline CNY-BNE & 3 & CNY-PHP & 4 & CNY-IDR & 2 \\
\hline CNY-CZK & 3 & CNY-PLN & 2 & CNY-HUF & 2 \\
\hline CNY-INR & 3 & CNY-QAR & 4 & CNY-AED & 4 \\
\hline CNY-ILS & 2 & CNY-RUB & 2 & & \\
\hline CNY-KWD & 1 & CNY-SAR & 4 & & \\
\hline CNY-MYR & 1 & CNY-SGD & 2 & & \\
\hline CNY-OMR & 4 & CNY-THB & 1 & & \\
\hline
\end{tabular}

This paper mainly analyzes the linkage between currency exchange rates of China and "One Belt And One Road" countries. Considering the development capacity and data availability of each country, it decides to analyze the regions along "One Belt And One Road" and select representative countries based on the exchange rate system. The representative countries selected in this paper are South Asia: brunei, Singapore, Malaysia, Thailand, Philippines; Central and eastern Europe: Russia. As can be seen from the above table, lag periods are different, but they all have significant mean spillover effect. India; West Asia: Saudi Arabia, Kuwait; Southeast Asia:

\subsection{ADF Test and ARCH Effect Test}

According to the test, the rate of return of currency exchange rate between China and the studied countries is stable, that is, there is no unit root phenomenon.

\subsection{Dynamic Correlation Estimation}

\subsubsection{Parameter Estimation}

Table 2 DCC parameter estimation table

\begin{tabular}{|c|c|c|c|c|c|c|c|}
\hline & $a$ & $\beta$ & $\alpha+\beta$ & & $a$ & $\beta$ & $\alpha+\beta$ \\
\hline CNY-BNE & $\begin{array}{c}0.0382 \\
\left(0.000^{* * *}\right)\end{array}$ & $\begin{array}{c}0.9222 \\
(0.000 * * *)\end{array}$ & 0.9604 & CNY-RUB & $\begin{array}{c}0.0117 \\
(0.000 * * *)\end{array}$ & $\begin{array}{c}0.9871 \\
\left(0.000^{* * *}\right)\end{array}$ & 0.9988 \\
\hline CNY-INR & $\begin{array}{c}0.0400 \\
(0.000 * * *)\end{array}$ & $\begin{array}{c}0.9457 \\
(0.000 * * *)\end{array}$ & 0.9857 & CNY-SAR & $\begin{array}{c}0.1284 \\
(0.000 * * *)\end{array}$ & $\begin{array}{c}0.8680 \\
(0.000 * * *)\end{array}$ & 0.9964 \\
\hline CNY-KWD & $\begin{array}{c}0.0174 \\
(0.000 * * *)\end{array}$ & $\begin{array}{c}0.9627 \\
(0.000 * * *)\end{array}$ & 0.9801 & CNY-SGD & $\begin{array}{c}0.0338 \\
(0.000 * * *)\end{array}$ & $\begin{array}{c}0.9349 \\
(0.000 * * *)\end{array}$ & 0.9687 \\
\hline CNY-MYR & $\begin{array}{c}0.0359 \\
(0.000 * * *)\end{array}$ & $\begin{array}{c}0.9506 \\
(0.000 * * *)\end{array}$ & 0.9865 & CNY-THB & $\begin{array}{c}0.0595 \\
(0.000 * * *)\end{array}$ & $\begin{array}{c}0.9008 \\
(0.000 * * *)\end{array}$ & 0.9603 \\
\hline CNY-PHP & $\begin{array}{c}0.0143 \\
(0.000 * * *)\end{array}$ & $\begin{array}{c}0.9853 \\
(0.000 * * *)\end{array}$ & 0.9996 & & & & \\
\hline
\end{tabular}

Note: P value in brackets; ${ }^{*}, *$ and $* * *$ mean significant at the levels of $10 \%, 5 \%$ and $1 \%$, respectively.

As can be seen from table $2, \alpha$ and $\beta$ are significantly not 0 , indicating that the correlation coefficient in the lag period is greatly affected by the residual standardized mean of the previous period. $\alpha+\beta$ reflects the persistence of the fluctuation between them, and the value of $\alpha+\beta$ is less than 1 , which satisfies the constraint condition. It can be seen that the correlation between China and the sample country has a very strong persistence feature. It is also found that $\alpha$ values are relatively small, indicating that the correlation between the current currencies is not significantly affected by the external interference from the previous period. The beta value than the all countries in the table 0.5 , brunei, Kuwait, Malaysia, etc of $\beta$ is opposite bigger, than the 0.9 , that correlation coefficient between RMB and most of the national currency exchange rate significantly limited by early, only a handful of currencies and the RMB exchange rate between the correlation coefficient is affected by the smaller degree, and has the characteristics of strong changes of sustainability.

\subsubsection{Dynamic Correlation Coefficient}

As can be seen from table 3, during the sample period, the mean value of the correlation coefficients between China and most of the "One Belt And One Road" countries is positive, which means that China and the sample countries have a positive correlation during the sample period. Some of them are almost 1, the smallest and all of them are negative, which means that the positive correlation is much bigger than the negative correlation. For Singapore, the mean, maximum and minimum of its correlation coefficients are all greater than 0 , indicating that the two countries are mainly positively correlated. From the perspective of the overall dynamic correlation coefficient, the correlation has some time-varying characteristics. 
Table 3 Descriptive statistics of dynamic correlation coefficients

\begin{tabular}{|c|c|c|c|c|c|c|c|c|}
\hline rho & $\begin{array}{c}\text { The } \\
\text { mean }\end{array}$ & $\begin{array}{c}\text { The } \\
\text { maximum }\end{array}$ & $\begin{array}{c}\text { The } \\
\text { minimum } \\
\text { value }\end{array}$ & $\begin{array}{c}\text { The } \\
\text { variance }\end{array}$ & $\begin{array}{c}\text { Partial } \\
\text { degrees }\end{array}$ & kurtosis & J-B & P \\
\hline CNY-BNE & 0.4123 & 0.6942 & -0.1119 & 0.0112 & -0.6643 & 4.1366 & 441.2048 & 0.0000 \\
\hline CNY-INR & 0.3511 & 0.7927 & -0.1578 & 0.0320 & -0.1467 & 2.3907 & 66.0065 & 0.0000 \\
\hline CNY-KWD & 0.1164 & 0.8028 & -0.5823 & 0.0157 & -0.3425 & 6.2879 & 1628.018 & 0.0000 \\
\hline CNY-MYR & 0.3866 & 0.7869 & -0.1228 & 0.0224 & -0.2950 & 3.1753 & 54.6757 & 0.0000 \\
\hline CNY-PHP & 0.3486 & 0.7800 & -0.0372 & 0.0403 & 0.1448 & 1.8281 & 210.3366 & 0.0000 \\
\hline CNY-RUB & 0.1710 & 0.5584 & -0.2178 & 0.0253 & 0.6103 & 2.8518 & 218.2312 & 0.0000 \\
\hline CNY-SAR & 0.6920 & 0.9566 & -0.0083 & 0.0363 & -1.4828 & 4.8419 & 1759.145 & 0.0000 \\
\hline CNY-SGD & 0.4265 & 0.6881 & 0.0596 & 0.0103 & -0.4651 & 3.1561 & 128.4296 & 0.0000 \\
\hline CNY-THB & 0.5181 & 0.9204 & -0.1246 & 0.0230 & -0.6458 & 3.8860 & 354.0825 & 0.0000 \\
\hline
\end{tabular}

\subsubsection{Trend of Dynamic Correlation Coefficient}

From figure 1, it can be seen that for brunei, the time-varying correlation coefficient fluctuates greatly and has multiple peaks, which are about 2007-2008, 2010-2011, 2015-2016 and 2017-2018. In 2007-2008, China was less affected by the us financial crisis, and the import and export trade with brunei increased significantly during this period, which increased the linkage between the two countries' currency exchange rates. The reform of the exchange rate between 2010-2011 and 2015-2016 made the RMB more market-oriented and benchmarking, which led to the linkage between the two countries' currency exchange rates. In 2017-2018, China was one of brunei's major trading partners in 2017, according to official statistics, which also explains the increasing linkage of currency exchange rates between the two countries.

For Kuwait, the peak in Kuwait occurred between the second half of 2015 and 2016, and has been relatively stable before and since then. The exchange rate reform of "August 11" in 2015 enhanced the benchmarking and marketization of the $\mathrm{RMB}$, thus increasing the linkage between the exchange rates of the two countries, which also shows that the linkage between the exchange rates of the two countries is affected by the reform of the exchange rate formation mechanism. For Saudi Arabia, there is not much fluctuation in these four stages, and the correlation coefficient is generally between 0 and 1 , indicating that the two countries are in a positive correlation.

For Singapore, the peak value of Singapore appeared in 2007-2008 and 2010-2011. The reason is that the exchange rate reform of RMB made the RMB more flexible, thus increasing the linkage between the two countries' currency exchange rates. The depreciation trend of the Singapore dollar around July 2016 led to a decline in the linkage between the exchange rates of the two countries.

For Malaysia, the first peak occurred in the first phase, 2005-2006; The subsequent peaks were in 2008-2009 and 2010-2011, respectively. From the point of time, in order to maintain the stability of the exchange rate, China has implemented the exchange rate system of re-pegging to the us dollar, which makes the RMB play a positive role in stabilizing the exchange rate of Malaysia. It can be seen that the linkage between the exchange rate of China and Malaysia is related to the market formation mechanism of the RMB exchange rate.

For India, the Philippines and Thailand, India had a small peak after July 2005, followed by three peaks in 2007-2008, 2010-2011 and 2014-2015. There were two peaks in the Philippines, the first around 2011 and the second around July 2015. Thailand had a peak in 2014-2015. The exchange rate reform in 2011 made the two-way fluctuation of exchange rate obvious, and the establishment of china-asean free trade area between China and asean provided an opportunity for the linkage between China and its currency exchange rate. China and India agreed to develop a closer partnership in May 2015, which shows that the deepening of trade and the strengthening of mutual cooperation can promote the linkage of currency exchange rates between them.

For Russia, the peaks were around 2006 and 2010-2011. It can be clearly seen from the time period that the 2008 global financial crisis intensified the risks in financial markets and weakened the linkage between the two countries' currency exchange rates. The reform of the exchange rate makes the $\mathrm{RMB}$ exchange rate more flexible and closer to the market exchange rate, which explains the increase of linkage. 

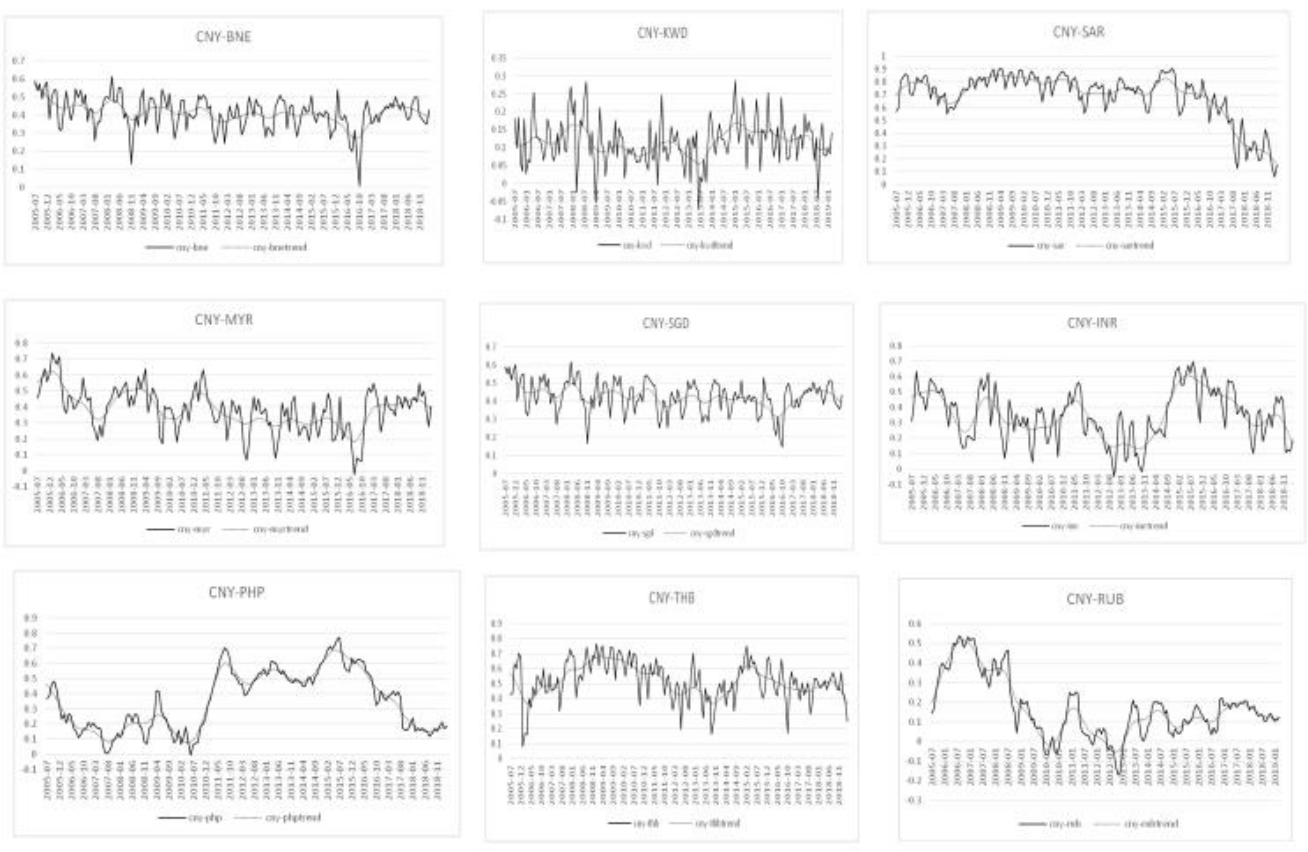

Figure 1 Correlation coefficient chart of the linkage between RMB and "One Belt And One Road" represents national currency exchange rate

\section{CONCLUSIONS RECOMMENDATIONS}

Ben mainly drew the following conclusions:

First, according to the results of VAR model, RMB has significant mean spillover effect on the countries along the "One Belt And One Road" selected in this paper, that is, the linkage described in this paper, which is greatly affected by the reform of the formation mechanism of RMB exchange rate.

Second, with the exception of the Philippines and Russia, the currencies of other countries have been relatively stable, and there is a positive correlation, which tends to be closer. Together, China and "neighbourhood" all the way along the route on behalf of the national currency of the correlation coefficient is relatively stable, but there is also a correlation coefficient of the volatile countries, India, the Philippines and Russia, for example, it also illustrates the RMB and the currencies of countries along the "area" the correlation between did not achieve full state of relative stability.

Therefore, in order to enhance the international influence of RMB and respond to the "One Belt And One Road" initiative, this paper proposes the following Suggestions:

First, carry out further reform of the RMB exchange rate system, establish a sound financial system to promote the full opening of the capital account, build a more effective financial legislation supervision system, and improve the two-way flexibility of the RMB exchange rate within a reasonable scope, so as to make the resource allocation efficiency of the financial market more effective.

Second, improve the level of economic development and further enhance the function of the renminbi as a safe-haven currency. As the us dollar still occupies an important position in the international market, when its liquidity risks rise, emerging economies will face competitive devaluation. At this time, improving the function of RMB as a safe-haven currency can promote the linkage between them to some extent.

\section{REFERENCES}

[1] Engle R F. Autoregressive Conditional Heteroscedasticity with Estimates of the Variance of United Kingdom Inflation[J]. Econometrica, 1982, 50(4):987-1007.

[2] Laopodis N T. . Asymmetric volatility spillovers in deutsche mark exchange rates $[\mathrm{J}]$. Journal of Multinational Financial Management, 1998, 8( 4) : 413-430.

[3] Ding jianping, Yang fei. Research on the linkage of RMB exchange rate with reference to the basket of currencies in east Asia $[\mathrm{J}]$. International finance research,2007(07):36-42.

[4] Guo jun, teng baihua. Analysis of exchange rate linkage between RMB, euro, us dollar and Japanese yen [J]. Economic issues,2011(07):95-99. 